\title{
Clio
}

Women, Gender, History

$38 \mid 2013$

Working Women, Working Men

\section{Italian working men's masculinities in the latter half of the twentieth century}

Masculinités ouvrières dans l'Italie du second $\mathrm{XX}^{e}$ siècle

\section{Andrea Sangiovanni}

Translator. Heloise Finch-Boyer

\section{(2) OpenEdition}

\section{Journals}

Electronic version

URL: http://journals.openedition.org/cliowgh/295

DOI: 10.4000/cliowgh.295

ISSN: 2554-3822

Publisher

Belin

Electronic reference

Andrea Sangiovanni, «Italian working men's masculinities in the latter half of the twentieth century », Clio [Online], 38 | 2013, Online since 15 September 2014, connection on 30 April 2019. URL : http:// journals.openedition.org/cliowgh/295 ; DOI : 10.4000/cliowgh.295 


\title{
Italian working men's masculinities in the latter half of the twentieth century
}

\author{
Andrea SANGIOVANNI
}

In Acciaio [Steel], a 2010 novel that takes place in the steelworks of Piombino, Silvia Avallone writes:

No one from outside can understand what it means to transform tonnes and tonnes of raw material. The hardest material that exists. And [the author adds] they could no more imagine the unbelievable quantity of sexy calendars and posters of naked women pinned up everywhere. ${ }^{1}$

The novelist repeatedly suggests the existence of a direct link between the way industrial workers experience being men, based on physical energy and aggressive behaviour, and their labour in the steelworks itself, in direct contact with heat, exhaustion and the constant emotional tension caused by danger:

You felt your blood flow at a crazy rhythm, when you were in there $[. .$. you regressed to a bestial state $[\ldots]$ You had a constant desire to fuck someone. The reaction of the human body to the titanic body of industry. ${ }^{2}$

Although her novel is set at the beginning of the new millennium, it portrays an image of workers whose key features seem to reproduce a traditional image: the steelworks are described as a completely masculine world, where the "natural" characteristics of man - strength, courage, leadership, honour, aggression - are praised to excess. Furthermore, these characteristics seem to be reduced to a basic level that denies them any of the political aspects that once characterized the image of the worker in socialist and communist

Avallone 2010: 86.

2 Ibid.: 23. 
culture. Thus, in Acciaio there is no trace either of "class consciousness" or of any "work ethic", not even the attention to a job well done. It is as if - given the progressive marginalization of manual work within production, as well as at a social and individual level, and the disappearance of the proud subjective identification of workers with their own trades - the only characteristics which could resist and give meaning to existence were those that defined the worker as male. In a way, this novel can therefore be considered as an end-point in representations of working-class masculinity which now seems, at the beginning of the twenty-first century when it is in profound crisis, to be above all a means of seeking reassurance. ${ }^{3}$

This article examines the development of representations of the worker as a man in Italy in the late twentieth century. Such representations result from the interplay between both the idea of the worker, and the idea of the man, two indeterminate representations which influence and - at least in part - shape each other. As a socialist and communist-inflected investigation into the working-class condition in the 1950s observed, it was not generally thought that there was "on one hand the man, and on the other the worker. The latter is a man because be is a worker. That is where his humanity is located. His being-a-man." 4

\section{Work and masculinity}

This layering of representations derives from the common perception that manual work is a foundational element of masculine identity. The importance of this perception has influenced lexical constructions, because "men usually make the verb 'to be' the indication of belonging to a trade" whereas "women use the verb "to do', followed by a distanced enumeration of numerous activities." 5 The link between work and identity is, however, relational: work forms a masculine identity which in turn influences the world of work. This holds true not only in the example of mining - where rigid gender barriers have prevented inter-communication between

3 Bellassai 2011: 17.

4 Onofri 1955: 29-30. My emphasis.

5 Pescarolo 1996: 322. 
the occupational sphere and the family sphere ${ }^{6}$ - but also in the textile industry where, despite an overwhelmingly female workforce, the division of labour and industrial relations have been marked by a clear gender hierarchy.

This article examines the case of metalworkers in engineering industries, in particular that of Fiat, where female presence had always been fairly low. In the 1970s, a special edition of the monthly company magazine Illustrato Fiat about women working in the company gave voice to women's growing demand for access to industrial work. The magazine sought to depict "modern" female workers who, it said, were no longer content to be housewives but wanted an occupation that would be really considered a proper job. Of course, said the magazine, their number was limited, but that was because engineering "demands [...] a particular type of preparation that women, partly because of their education, very seldom succeed in obtaining." 7 The situation was hardly any different in office work, even if the number of female employees was higher there in percentage terms than that of female workers in the factories. Once more, the division of labour was strongly influenced by gender difference.

All in all, despite the relatively high number of women in employment in the $1970 \mathrm{~s},{ }^{8}$ work was still considered to be a masculine prerogative and its iconography was anchored to images of machismo. To be sure, this image was no longer rigidly linked to the stereotype of male worker typical of the 1950s:" "sober, virile and strong, robust and reassuring, threatening if in a group, depicted as clean-shaven and radiant, if possible in shirt-sleeves and canvas or cord trousers". ${ }^{10}$ Nonetheless, as late as 1972, an Ennio Calabria poster continued to reflect this traditional visual language by drawing

6 Contini 1999 [1997]: 280-281.

7 Illustratofiat 1975.

8 Paci 1973.

9 This image, principally derived from communist culture, also influenced the collective imagination, such as the film by Eduardo De Filippo Napoletani a Milano [Neapolitans in Milan] (1953) or the first industrial novels of the 1960s (Ottiero 1959: 139; Bianciardi 1998 [1962]: 53).

10 Ballone 1987: 163. 
a working man in overalls, arms folded, looking larger and even more imposing because of the extreme worm's-eye angle, gazing into the distance at an undefined future of social rebirth. ${ }^{11}$

\section{The workplace as masculine community}

Workplaces also appear to be represented as masculine communities. In 1955, a year after being laid off, a worker wrote to his workmates "I loved the factory", this "community of hard-working men, united by effort and the desire for a fairer future [...] I still feel like one of your brothers."12 Another describes how the factory consisted of "comrades, friends, it was the atmosphere, how we used to discuss things, how we talked, the solidarity there". It was a place where experience was inherited through the male line, because there the worker found "the smell that my father brought back from work when he came home, when I was a kid". ${ }^{13}$ Aside from these statements where memory of the factory seems to have been influenced by nostalgia, we might think of two standard images used to evoke the factory: on one hand, the prison and the barracks, both exclusively masculine locations of harsh working conditions. And on the other, the "community", a place made up of networks woven from masculine solidarity which often took on a political colour, ${ }^{14}$ but which was also defined by eating together and a shared passion for sport. ${ }^{15}$ This polarization continued even in the most intensely politicized moments of factory life, for example during the period of strikes between 1968 and 1973.

Andrea Papaleo's statement, as a Fiat worker and member of Lotta Continua, ${ }^{16}$ is therefore illustrative:

I thought that the factory was the centre of everything $[\ldots]$ even if the work wasn't easy [...] Even if it seemed that the discussions you had outside were more profound, in the factory things were truer. Perhaps you talked

\footnotetext{
11 The image is available at the following website: http://manifestipolitici.sebina.it/sebina/repository/opac/link/ams_cal/ams_cal_059.jpg

12 Mario Colombo in Garigali 1995: 107. My emphasis.

13 Garigali 1995: 41.

14 Bertuccelli 1997: 22.

15 Passerini \& Filippa 1997: 337; Portelli 2008: 90-93.

16 Extreme left-wing Italian political organization
} 
more about women and football than about politics, but no-one was faking, no-one was playing a part. ${ }^{17}$

Moreover, even the strategies used by women workers to make the factory less sanitized and impersonal, such as putting a bunch of flowers next to their machine, can be read as a kind of opposition to the masculine connotations of the workplace. Male workers emphasized this opposition by their own personalizing of their work space: in a scene from the 1971 Elio Petri film La classe operaia va in paradiso [The Working Class Goes to Heaven] one workstation is decorated by a poster depicting a nude woman. This practice was still occurring at the end of the 1970s, when the activists of the Turin Womens' Inter-professional Union demonstrated and made "punitive"-type raids, pulling down and binning posters and porn magazines stuck on office walls. ${ }^{18}$

\section{The factory, after school and the barracks}

Despite their variety, company models of representing the factory also suggest the idea of a masculine community. Thus Fiat promoted an image of its own world based on a hierarchical conception of existence, viewed for the most part through the prism of masculinity. The Fiat apprenticeship college (Scuola Allievi Fiat) is particularly interesting for this reason; it is depicted in all the films that describe company welfare programmes, and one 1962 film is entirely based on the college. ${ }^{19}$ The reference models, including their visual language, are the barracks or the high school, with pupils in uniform marching in formation, and performing the same movements. These are representations depicting a masculine model which probably had a normative value for the company to the extent, as Simonetta Piccone

17 Polo 1989: 213. My emphasis.

18 Giorda 2007: 216-217.

19 See the company films Opere Sociali Fiat (1957), Accanto al lavoro Fiat (Claudio Solaro, 1962), Oltre il lavoro (Adriano Di Majo, 1973), a trilogy about the Fiat social programmes and La Scuola Allievi Fiat "Giovanni Agnelli" (Stefano Canzio, 1962). Opere sociali is archived at l'Archivio e Centro Storico Fiat; the other films can be watched online at www.cinemaimpresa.tv 
Stella notes, that it was commonly thought in the 1950s and 1960s that "youth was simply an apprenticeship for adult life." 20

Moreover, the same references appear in a photographic series from the early 1970s, which shows other Fiat company welfare programmes, such as the "apprentice houses" (case per lavoratori apprendisti). ${ }^{21}$ Again, these images show an exclusively male community. Once more, the spatial organisation, the furniture and the sanitized atmosphere evoke either a high school or a barracks. It is as if the interior and the exterior of the factory worked together to define a unique model both of a man and of an orderly, disciplined worker, with few and simple entertainments like playing cards or, at best, reading a magazine. Some of these photographs, however, show working men cooking: these are images which definitely depict a world without women, yet which push the viewer to ask to what extent the social transformations emerging from the economic boom transformed traditional models of virility. For male workers, this change overlapped with the transformation of manufacturing and the factory environment in addition to the transformations wrought by the revival of trade unionism. ${ }^{22}$

\section{Changes in working-class masculinity}

During the "economic miracle", the most attentive observers of Italian reality - from literature to cinema, from newspaper investigations to the social sciences - began once more to enquire into the factory world, by picking up faint signals of the transformation of working-class masculinity. Giuseppe Fina's Pelle viva [Scorched Skin, 1962] relates in a late neo-realist mode the difficult life of a worker obliged to commute between his home and his workplace. The director's main intention is to criticise his harsh working conditions, but he also shows the subtle changes of the family as an institution, because the main character marries - in a civil

20 Piccone Stella 1993: 28.

21 Archivio e Centro Storico Fiat, busta OS337, series "Case per lavoratori apprendisti" (1971), partially reproduced in Images from the Fiat Archives, 19401980. Milan: Fabbri editori. 1990: 86.

22 Sangiovanni 2006. 
ceremony - a young woman immigrant from the Mezzogiorno who already has a child.

\section{A weakened workforce?}

In other cases, however, changes to basic elements of the traditional model of workers' masculinity were more obvious. One such was representation of the body, which has always been central to the written and visual construction of the image of the manual worker. The male worker has long been represented by an image of his own body: the iconography of the nineteenth century often showed him stripped to the waist, in order to highlight his muscle structure, contrasting with the flabby and unfit bodies of the "bosses". Even in the 1950s and 1960s, there were frequent representations of the worker as "a demiurge", a "gigantic figure without whom humanity would stop",23 such as the muscular workers wielding heavy iron hammers depicted on the membership cards of the communist party in 1952 and 1961.24

In 1962, however, Paolo Volponi questioned this representation of the worker's body in Memoriale [Memorial], one of the most important "industrial" novels of Italian literature. The story centres on the main character's body: Albino Saluggia is suffering from pulmonary tuberculosis, but he is hired at the factory because of his status as ex-prisoner of war. The novel relates both a psychological and physical pathology, and follows the slow and inexorable decline of Saluggia's health. Alongside the central plot however, Volponi follows the way the increasingly mechanized factory transforms the bodies of the workers. Thus, Saluggia notes in relation to his work colleagues that

each one had a tensed muscle, pursed lips, half-closed eyes or furrowed eyebrows. In other words, they all had but one thought beating away in their heads, bouncing off all the walls of the factory, and beating on. The factory gave no respite to these thoughts $[\ldots]$ it was not enough to lift their eyes from the work and look around; there was nothing that was not part of the factory. The work itself did not help; it did not require

\footnotetext{
23 Bertuccelli 1997: 219.

24 Novelli 2000: 69 and 163.
} 
the guidance of thought [...] It was only after work that we finally seemed to see men in the factory. ${ }^{25}$

True, the theme of factory rhythms that annihilated both body and thought was not particularly new, but the attention that the question aroused in public opinion was new. At the end of that decade, Giorgio Bocca devoted a number of his columns in Il Giorno to this subject and coined the expression the neurotic factory" 26 a place where "machines get younger and workers age before their time" 27 and where "men and machines live together with difficulty", a state of affairs which produces

a maladjustment to the working environment and its dangers [...] then devastating epileptic seizures, individual and group explosions which bring in their wake new repressions and frustrations and their consequences, industrial accidents, absences, spontaneous strikes, sabotage and, sometimes, madness. ${ }^{28}$

The neurotic factory, Bocca stated, influences life even when workers adapt "their lives to continual exhaustion, giving up any tiring leisure activities, sleeping more, reading less" 29 and, one could add, making love less often. This grievance, which became a topos of working protest in the following years, ${ }^{30}$ destabilized one of the foundations of working-class masculine identity.

The previously mentioned film The Working Class Goes to Heaven demonstrates, however, that the deconstruction of this aspect of masculine identity did not develop in a linear way. Lulù Massa, the film's main character, appears as the prototype of "the good worker", embedded in consumer society and the productive system. His only concern is to get maximum benefit from his own work and because of this the management asks him both to define the time needed for

25 Volponi 1991 [1962]: 112. My emphasis.

26 He devoted seven columns, published in February and March 1968 to the subject of "the social cost of labour". The phrase appears in Il Giorno, 29th February 1968.

27 Il Giorno, 25 February 1968.

28 Il Giorno, 29 February 1968.

29 Il Giorno, 5 March 1968.

30 One photograph shows a placard held up during a trade union demonstration in Turin, representing two hearts superposed on to each other with the heading "We can only do this if we work less". Archivio e Centro Storico Fiat, b. 6/20, 1971. 
making parts and to train new employees. In one scene, Lulù explains to two young men who have just arrived how to work one of the machines; and when they ask him how he manages to keep up with the rhythm of work he replies:

I've got this technique to help me concentrate. I get an idea in my head: I think of an arse, the arse of that girl over there. In here, there's nothing else to do; what else can you do?

In the following scene, the camera frames Lulù in front of his machine while he works at a rapid rate and obsessively repeats "One part, one arse. One part, one arse..." The camera then follows the two young men who start to smash the machines in an act of rebellion, before returning to Lulù who, completely unaware, continues to produce the parts without ceasing his mantra. Beyond the symbolic force of the scene, the portrait of Lulù is the most interesting. His repeated and obsessive macho utterance is nothing more than a form of nervous tension, belied by other scenes that cast doubt on his real sexual performance. Yet the factory has damaged Lulù's whole body: "I am thirty one years old," he says. "I've been in the factory since the age of fifteen. I have been poisoned by paint twice and I have an ulcer. I'm broken inside". It is perhaps no accident that Lulù's rebellion is finally precipitated by his losing a finger, another violation of his body.

All the same, despite increasing awareness of how factory rhythms negatively impact on sexuality, one can detect a kind of reaction in defence of working-class virility, weakened and compromised as it had been. For example Il padrone e l'operario [The boss and the worker] a minor film by Steno [Stefano Vanzina], plays on the opposition between the virile worker and the unmanly boss. One could also cite the case of workers in the 1968-1969 period, who sometimes described their complex relationship with [left-wing] students in ways that were also underpinned by sexual factors.

The ageing worker who, for years, had felt himself to be an inferior being [a leading campaigner of that time related] suddenly found himself 
face to face with a teenage girl who was interested in him and told him he was the centre of everything. ${ }^{31}$

This is echoed in a report by Gad Lerner, a far-left activist at the time:

It was lovely to watch the parade in front of the Milanese Lotta Continua premises on Saturday afternoons when the teenage girls [...] from Berchet High School encountered Militich de Pirelli and the other workers who touched them up and they let themselves be touched, they played about with that. ${ }^{32}$

Another activist from Lotta Continua, Vicky Franzinetti, remembered that young women sometimes got engaged to workers of their own age: "they would go to the cinema with them, share their interests and copy their way of dressing". She added, "We needed to be forgiven for being daughters of the bourgeoisie. People told some of the women (and some women said it too) that you had to go out with the workers". 33

This demonstrates once more that the changing models of masculinity were not linear, even in the social milieus that might have been most likely to accept such change. The publication of a Gasparazzo comic strip featuring Lotta Continua, for example, created a lot of bad feeling. Drawn by Roberto Zamarin, the character Gasparazzo was depicted as an immigrant worker from the south who, as Goffredi Fofi has noted, "looks at the world of the factory, and industrial society, with the astonishment and the artlessness of a child but also with the consciousness of age-old exploitation." 34 In the Lotta Continua drawings, Zamarin shows him fondling the bottom of a girl who is distributing the Lotta Continua magazine in front of the Fiat factory gates. Furious, she brings up the issue in a committee meeting which agrees, "no fondling the Lotta Continua girls' bottoms will be allowed". Gasparazzo is persuaded, stops touching up the Lotta Continua girls, but moves on to fondling the bottoms of girls in Potere operaio instead (another far-left

31 Polo 1989: 152.

32 Cazzullo 1998: 83. My emphasis.

33 Cazzullo 1998: 254.

34 Fofi also notes that "Gasparazzo is not a typical case but an average: he represents, is intended to represent, working class humour in its current form, in its shared maturity and force." Fofi 1972: 128. 
group). ${ }^{35}$ The comic strip highlighted, in an ironic and farcical way, the "woman question" which would later fuel strong disagreements among far-left groups, and yet which was already beginning to foster the appearance of a new masculinity. The persistence of oldfashioned gestures of virility of a "slap and tickle" kind focussed discussions on a new model of gender relations based on "friendship and complicity". As Vicky Franzinetti, one of the people who protested against the comic strip remembered: "among older generations, segregation was the rule, men and women lived separately and did politics separately. But we thought we should be comrades and companions." 36

\section{Education of the workers and transformations of daily life}

To understand fully the significance of the change this episode marks, it must be contextualized within broader transformations of youth culture, because the arrival of a new wave of young workers in the 1960s also influenced the world of the factory. Whilst young people were still seen as adults being trained, they began to see themselves as peer-groups based on "a network of horizontal links inside the vertical institutional structures which had, until then, been internalized". ${ }^{37}$ Young people saw each other as peers because of the way they dressed, the music they listened to, what they read; in short through the informal culture conveyed by the media, rather than through the formal culture of educational institutions or traditional behavioural norms. As the daily press noticed in 1969, the workers who stopped

to talk with the students at the [factory] gates, are mostly young southerners. They don't seem in any hurry to go back home. [...] After eight hours of working on a factory line, it's a relief to listen to other young people and talk with them. ${ }^{38}$

35 Zamarin 1972: 90-91. Potere Operaio is another Italian extreme left political group and newspaper.

36 Cazzullo 1998: 254.

37 Piccone Stella 1993: 53.

38 Mario Monicelli, L'Espresso, 9 November 1969. 
This transformation modified gendered interactions, albeit slowly, and made it possible for women to have an active role. ${ }^{39}$ It also changed men's relationship to their work, which affected another element of masculine identity: if the older workers were sorry to see a "work ethic" disappearing, the new generations of workers sometimes even refused the sense of belonging to the masculine community of the factory. In the words of Giampiero Carpo, a worker who had nonetheless gone through the Fiat apprenticeship scheme:

For me, as for a whole lot of young workers, it was one of a range of options; if things didn't go well in there, we could go elsewhere and we were no longer willing to accept injustice beyond a certain limit just in order to keep our job. ${ }^{40}$

In short, patterns of working-class identity were slowly changing; from now on, this identity would include what was happening outside the factory, both in public and in private life, contributing to what Luisa Passerini and Marcella Filippa have described as a "multiple identity" 41 where diverse affinities did not conflict with each other, but were layered and mutually enriching.

Growth in consumer consumption and transformation in living styles added to this. The development of the market, and especially of leisure consumerism was no longer reachable only through male mediation but was directly aimed at female consumers, "destabilizing the women-men-market triangle" and dealing "a serious blow to virile masculinity". ${ }^{42}$ This is shown, for example, in the pathetic attempt by Giulio, a Milanese worker of advancing years, who goes to long sessions in a male beauty salon in an attempt to win back his young wife Vicenzina, who has fallen in love with someone else - Mario Monicelli's warm and ironic portrayal of a working class couple in his 1974 film Romanzo popolare [Come Home and Meet My Wife]. The director reveals the fracture in the classic model of working-class masculinity and, at the same time, shows a new model of masculinity - brought to the fore by 1960s magazine advertisements - whereby

\footnotetext{
39 Giachetti 2002.

40 Polo 1989: 114-115.

41 Passerini \& Filippa 1997.

42 Bellassai 2011: 106.
} 
men use cosmetic products without losing their virility. Thus, the film depicts a multiple masculine identity and yet has little or nothing to do with traditional masculine models.

Another film from the same period, Delitto d'amore [Somewhere Beyond Love] (Luigi Comencini, 1974) takes a young woman worker as its narrative focus, and effectively its main character. Again, in this example, the man is represented as having an increasingly fragile identity and appears to try to bolster his lost virility by salvaging outdated models. Nullo, a Milanese worker who sees himself as an anarchist, meets and falls in love with Carmela, a southern worker at the factory. Their relationship is made more difficult by their social and geographical backgrounds: Carmela's desire for independence becomes a battleground, as her brothers try to stop her, sometimes forcefully, from meeting up with Nullo. When the young woman dies, poisoned by toxic products from the factory, Nullo (who by this time has married her) seems to adopt the cultural models of his inlaws and takes blood revenge for his dead wife by shooting the factory owner. The reception of this film was very hostile, with sharp criticism of the way the worker's private life overtakes his social commitments. From today's perspective, this could be seen as a forerunner of a broader decline in collective action, that would become more obvious in the following years.

At the beginning of the 1970s then, an increasing number of signals heralded the profound transformation of the working-class, even if they stayed hidden behind perceptions of the Italian "hot autumn" of 1969. ${ }^{43}$ Comparing two covers of the Catholic weekly Famiglia cristiana helps to elucidate these representations of masculinity. In 1969, the cover dedicated to the First of May portrays a close-up of a man wearing blue overalls and a yellow safety helmet. On the cover of the first issue of 1971 the weekly newspaper portrays a woman working on a welding machine (under a headline announcing "Women and heavy engineering"). ${ }^{44}$ Another sign was the creation in 1975-1976 of the women's coordinating group within the metal federation FLM (Federazione Lavoratori Metalmeccanici) arising from the development of

\footnotetext{
43 Sangiovanni 2006.

44 Famiglia Cristiana, 27 April 1969, 3 January 1971.
} 
feminism in an almost exclusively male-dominated trade union movement which had previously given little serious thought to the female question beyond a declaration of principles, at least until 1974. ${ }^{45}$ In both cases, however, the new role of women was held back by the slow-changing traditional representations of factory work as a masculine arena. Thus, the female images which illustrated the cover and the article in Famiglia Cristiana appeared alongside the statement that heavy engineering "demands special physical and psychological qualities, talents and aptitudes which are, without doubt, confined to men". ${ }^{46}$ As for the women delegates from the presses section at Fiat, before interviewing the female workers, they had to "ask for the agreement of the [male] operators and then the male delegates of the Fiom-CGIL" who issued "imperious injunctions: What do you want to talk about? We're very serious here, here there are some things that are better left unsaid". ${ }^{47}$

\section{Renegotiating domestic labour}

Despite the reinforcement of traditional representations of masculine identity at the beginning of the decade, profound but subtle shifts also began to occur. This is evident in the brief messages that Vittorio and Nives Sparati, a working couple on the three-shift system, send to each other [in Alberto Papuzzi's 2007 novel Quando Torni: Una vita operaia, set in the 1970s]. They write these messages to organize household and family activities, as they find it difficult ever to see each other. These messages illustrate the couple's innermost transformations, sometimes becoming a kind of private diary. ${ }^{48}$ In the Sparati household, the daily management of the house is equally divided. Vittorio cooks, does the shopping and the cleaning; and in 1978, he even discovers the pleasure of looking after himself and his own body, as if he was in tune with the broader retreat into the private sphere which would characterise the "reflux", the changing social tide. ${ }^{49}$ Despite this continual redefinition of his own identity,

\footnotetext{
45 Cereseto, Frisone \& Varlese 2009.

46 Famiglia Cristiana, 3 January 1971.

47 Statement by Tina Fronte in Giorda 2007: 134.

48 Papuzzi 2007.

49 Ibid.: 54. On the term "reflux" see also Morando 2009.
} 
however, Vittorio's traditional masculinity sometimes emerges, for example during a discussion on the division of household roles, which results in the couple's temporary separation. ${ }^{50}$ As Sandro Bellassai has remarked, the "renegotiation of domestic labour" which gained a foothold in the 1970s was often a pragmatic necessity which did not necessarily imply that men had signed up to the new behavioural models proposed by the women's movement. ${ }^{51}$ In 1979, Carla Ravaioli was perhaps a little too optimistic when she wrote that "feminism's challenge to hegemonic masculine roles has unquestionably modified the behaviour of a significant number of men". ${ }^{52}$ The tensions characterizing the relationship between male workers and women inside the Lotta Continua movement are symbolic in this respect: during the 1976 Rimini congress, a working man maintained that "only the [male] worker, as a worker, can express what the proletariat expresses. The woman, as a woman, does not always express what the proletariat expresses." 53

\section{Transformations of work and the redefinition of masculinity}

In reality, it was not only the working-class model of masculinity that underwent a profound change at the end of the 1970s, but also the entire world of the factory, in a series of processes that mixed and fed into each other. The relation to work changed and these changes were profoundly linked to the generational tensions that characterized the 1977 events. Furthermore, this change underpinned a number of contemporary analyses that attempted to explain "this strange movement of strange students." 54 During those years, the concept of

50 Ibid.: 58-60.

51 Bellassai 2011: 129. The practice of this "practical egalitarianism" in the management of domestic affairs does not prevent adherence to a traditional family model with the man at work and his wife in the house. Thus Vittorio Sparati is convinced that if Nives "didn't go to work, ah, well, everything would be really different. I say it all the time, if I earned 800 smackers a month all our problems would magically disappear". Papuzzi 2007: 59.

52 Ravaioli 1979: 355.

53 Cazzullo 1998: 270.

54 Lerner, Manconi \& Sinibaldi 1978. 
"the refusal of work" was increasingly evoked: theorists of workerism [operaismo] saw as one of the decisive factors of the 1970s the transformation of the "mass worker", typical of 1968-1969, into the "social worker" in the "social factory". 55 But literature would also do this: take the words of Boccalone, the main character of a 1979 novel: "my desiring machine is not synchronised with the work machine". ${ }^{56}$

In between times, moreover, the working environment changed, as much in the small and medium-sized companies that were to typify the emerging "third Italy" 57 as in heavy industry. At Fiat there was a transition from "permanent conflict" to "a productive truce" which changed the behaviour of the working community. Collective action tended to die down in favour of a private sphere and while "not so long ago [a worker said] we all shouted together, nowadays we all mutter in little groups, as if we were in the market square". ${ }^{58}$ One journalist remarked that an absolute refusal of "industrial values: productivity, work, the factory" appeared to spread, without anyone realising that these industrial values were also precisely the "values" of trade union culture. Similarly, relationships with the traditional collective forms of struggle were changing as well: new models marked by subjectivity and creativity began to replace them.

The demo, the picket line, the meeting, are interesting like bappenings, [wrote the same journalist] as an occasion for boys and girls to meet, to go out with each other, to make love, and that also happens at the factory during a strike. ${ }^{59}$

These new kinds of behaviour clashed with the widespread culture at Fiat amongst the older workers and the "foremen", who were intermediary subjects between the large mass of the workers and the management. "Should people be able to make love in the factory?" asked a letter sent in January 1977 to the company newspaper Il giornale dei capi [The foremen's newspaper]. "For me, the right to make love in the factory seems inconceivable," wrote the correspondent.

\footnotetext{
55 Negri 1979.

56 Palandri 1988 [1979]: 43.

57 Bagnasco 1977.

58 Revelli 1989: 69-70.

59 Giustolisi, L'Espresso, 22 July 1979.
} 
He added that this kind of behaviour signalled a general deterioration of the entire country, which had started with lack of interest in work. "I respected work my entire life, and I continue to do so, and I've seen that all the problems of the country began when such respect was considered idiocy". 60

Moreover, towards the end of the 1970s, the youngest generations started refusing not only work but the overall working environment, including the most common model of masculinity:

Look at me, look at me properly [said Giò, aged 20, in July 1979]. I'm wearing disco shoes, an extremist's shirt, a homosexual's earring and I've got long hair like a singer: nothing that makes me look like a factory worker! Because if anyone comes in here, into the workshop, I want them to understand immediately that I'm not like the others. [...] Outside I can walk around without my earring, dressed normally, but here I have to signal my difference. ${ }^{61}$

Giò's search for difference also shows that the process that began in the previous decade had come to fruition, namely a construction of multiple, sometimes contradictory, masculinities that nonetheless never relinquished virility. It could happen therefore that men active in the trade union looked after children, or might even bring them along to factory council meetings. ${ }^{62}$

Once more, however, the evolution of working-class masculinity, notwithstanding its specific features, reflected a broader social transformation. In summer 1978, Il Corriere della Sera published a letter on its first page in which "a fifty-year-old professional", unable to choose between his wife and his mistress, stated that he wanted to take his own life because of love. This was one of the first signs of this "triumph of private life", to which the concept "reflux" or ebbing tide was applied. This was a social attitude which Il Corriere della Sera (the most widely read newspaper in the Italian press at the time) was not only happy to write about, but which it had almost encouraged. In fact, a journalist's recent reconstruction of this affair states that the letter was probably a piece of writing created by the

\footnotetext{
60 Unsigned letter, Il giornale dei capi, January1977.

61 Interview in Revelli 1989: 81.

62 L'altra metà del cielo. Giornale delle donne in Fiat / F.L.M., no 1, September 1980.
} 
newspaper's editors, based on a marketing survey that made predictions about the future direction of public opinion, "[a shift from] political participation to nascent individualism, from a desire for order to a revival in religiosity." 63

This resonates with some research that Fiat commissioned from the Demoskopea institute in 1979, whose aim was to study the "change factors" in complex societies, in other words the "vectors through which it can be hypothesized that changes will occur in our society". ${ }^{64}$ Amongst the transformations that Demoskopea predicted were both the "refusal of work" and a modification of the traditional values attributed to the "working class". Significantly Demoskopea noted in relationship to the family that it "no longer constitutes an end in itself, either for the woman or the man", and "marriage is no longer seen as the sign of entry to the adult world". This transformation in the institution of the family arose out of general anti-authoritarianism, which made traditional hierarchical organization more difficult, and which, in a more general way, brought about

a radical fault line in the social conditioning intended to encourage acceptance of the authority of the state, and of institutions where paternal authority constituted the symbolic reference point and the most efficient instrument of pre-disposition. ${ }^{65}$

Transformations of the family and the role of woman as agent, noted Demoskopea, seemed not to affect the figure of the male, because "men do not change at the same rate as women". In reality, however, beyond the apparent equality of gender relations, a real upheaval of traditional identities was taking place, which for men would result in "growing insecurity and an enormous identity crisis." 66

63 Morando 2009: 35-36.

64 Demoskopea, IV rapporto: Il cambiamento della società italiana - tipologia della popolazione italiana from December 1979, p. 1, Archivio e Centro Storico Fiat, Segreteria dr. Luigi Ferro, busta n. 56, "Demoskopea anni 1978-1979-1980”.

65 Demoskopea: 5-6.

66 Demoskopea: 8-9. 
It was at exactly the same time that magazines started giving an important place to light-touch articles describing "the male crisis", ${ }^{67} \mathrm{a}$ subject which was also developed effectively by Marco Ferreri in his 1978 film Ciao maschio [Bye Bye Monkey]. ${ }^{68}$ But the most interesting film from the point of view of working-class communities was pure comedy entertainment La patata bollente [Hot Potato], filmed by Steno [Stefano Vanzina] in 1979. With an ambiguous title alluding to erotic comedy, this film dramatizes the political and personal crises of a worker (played by Renato Pozzetto) who is an uncompromising communist, union rep and one-time boxer with superhuman strength. His character, nicknamed Gandhi, is the quintessential virile worker. However, his encounter with Massimo Ranieri, a homosexual whom Gandhi saves from a fascist lynching, and who is then put up by Gandhi in his house, makes him question himself and his own convictions. On a symbolic level, therefore, masculine "deviance" causes cracks in the exaggerated virility of the main character, but at the same time this virility is not rejected, and ends up redrawing the representation of working masculinity in a new way. ${ }^{69}$

The film therefore describes (sometimes in a vulgar register) the profound transformation in a working-class world that is increasingly difficult to represent as a monolithic bloc. Perhaps, as a communist Fiat delegate affirmed, "we are beginning to understand that this working class has changed, and that there are no longer simply generational differences, but also differences in income and culture". ${ }^{70}$ The same year, the Italian communist party had carried out an impressive mass study on industry, which drew an unexpected portrait of the working-class world. ${ }^{71}$ This was confirmed a few years

67 Riotta, L'Espresso, 19 February 1978: 7.

68 Reviewed by Moravia under the headline De profundis, maschio, in L'Espresso, 12 March 1978.

69 On the ambiguous relationship between homosexuality and the male factory environment see Pennacchi 1994: 66-67.

70 D'Agostini, Rinascita, 15 June 1979.

71 A. Accornero, A. Baldissera, S. Scamuzzi, "Ricerca di massa sulla condizione operaia alla Fiat: i primi risultati”, Bollettino Cespe, 2 February 1980; G. Bonazzi, "La lotta dei 35 giorni alla Fiat: un'analisi sociologica", e F. Carmignani, "Il 'sindacato di classe' nella lotta dei 35 giorni alla Fiat", interviews in Politica ed 
later by a new piece of research which described a "multi-dimensional worker" in the sense that

alongside the working man, other faces and other interests began, in turn, to assert themselves: that of the income gatherer, the saver, the consumer, the producer, the skilled professional, the (conscious) holder of resources of power and influence, and so on. ${ }^{72}$

And yet, once more, traditional images and representations were extremely slow to change. It is no accident that gendered and generational dimensions marked two of the most significant fractures of this period, as a long headline in Corriere della Sera effectively demonstrated..$^{73}$ "The young woman enters the factory and is put to work in the foundry. If she complains, they tell her: you wanted sex equality, didn't you?"

All the tensions and fractures which had weakened the labour and union movements - from terrorism to the transformation of the forms of production, from the ossification of internal forms of representation to the arrival of new generations of workers - led to a double defeat at the beginning of the 1980s: the famous "March of the Forty Thousand" in 1980, [when a strike at Fiat was broken by other workers] and the 1985 referendum [which saw the rejection of inflation-proofed sliding pay scales in industry]. ${ }^{74}$

Defined at the end of the 1980s as "the class that no longer exists" 75 the workers had already demonstrated at the beginning of that decade that they had "changed skin" to use an expression of the newspapers at that time. ${ }^{76}$ It is significant that the L'Espresso edition of 26 October 1980 (in which the union defeat at Fiat was announced) contained two opposing representations of working masculinities. On one hand, there was a photograph of an older man

economia, 11, 1984; A. Accornero, A. Baldissera, S. Scamuzzi, "Le origini di una sconfitta: gli operai Fiat alla vigilia dei 35 giorni. Ricerca di massa sulla condizione operaia", Politica ed economia, 12, 1990.

72 Urbani \& Weber 1984: 83.

73 Pertegato, Corriere della Sera, 27 November 1979.

74 Bertucelli 2004.

75 Lerner 1988.

76 Turani, La Repubblica, 22 February 1980. 
in blue overalls, who appeared to be clutching a red flag with an expression of disappointment and bitterness, the very symbol of defeat, reflected in the headline $W$ oe to the defeated! [V ae victis]. On the other hand, a photograph illustrating an article on part-time work showed a half-length portrait of a man looking serene, half-smiling, wearing both overalls and casual clothes at the same time, and holding a bunch of flowers. This symbolic juxtaposition, while probably involuntary, signalled the irresolvable crisis in working-class masculinity linked to the end of Fordism and of the centrality of work as a value of identity. It is no surprise, therefore, that the main character of the above-mentioned fictionalized biography Quando Torni decides to stop being a worker in the 1980s. This decision has consequences, because Vittorio Sparati leaves the factory to start his own business and "was conscious of appearing substantially different from the man he had always been. Of appearing to himself like this." 77

This type of existential transformation is recorded in two 1994 films, Paolo Virzi's La Bella vita and Padre e figlio [Father and Son] by Pasquale Pozzessere, in which representations of the factory world return to the cinema after a long absence and offer a vision of a radically changed manufacturing sector: through a decrease of the active workforce employed in industry (declining from 37.6\% in 1980 to $32.5 \%$ in 1995) and the reconfiguration of values and imagery linked to work, accompanying the attempt to introduce a "culture of flexible working". ${ }^{78}$ In both films, the growing marginalization of a particular industrial world causes an identity crisis in the leading characters, not only the identity shaped by their work, but, more broadly, affecting their masculinity. In La Bella vita, the worker played Claudio Bigagli loses his job, throwing his relationship with his wife, a supermarket cashier, into disarray. She then falls in love with a local television presenter. The two models of masculinity are obviously juxtaposed, as if they belonged to two separate eras, and two types of work: the first linked to the material world - specifically the steel

77 Papuzzi 2007: 165. My emphasis. See also Pennachi 1994.

78 Loy 1999. 
produced at Piombino - and the second linked to an almost complete dematerialization. ${ }^{79}$

If therefore, new virile identities were being redefined during the 1990s, by the requirements of marketing and advertising, rather than by belonging within social categories, the model of working-class virility seemed to be constantly on the wane. Peter Cattaneo's 1997 film The Full Monty is exemplary in this sense. In this English film - which was very successful in Italy as well - a group of unemployed workers decide to become strip-tease performers to make ends meet. By reawakening their relationships with their own bodies, they reconstruct a masculine identity that had been shaken by their loss of work. This new corporeality is precisely the central axis for the different macho image constructed by consumer markets. ${ }^{80}$

In this sense, the workers described by Silvia Avallone's novel Acciaio, quoted above, seem to be particularly representative. The novel is continuously shot through with a rigid, separation of social roles, according to gender. The young "seventh generation" workers no longer seem to have any commitment at all to their work: in the steelworks, writes Avallone, "they have fun riding the diggers as if they were bulls, listening to music at full volume, with an amphetamine pill under their tongues" 81 but their lives play out far from the factory, pursuing models of virility linked to the possession of what money can buy.

Far from the traditionary set of images of the factory, the fictional workers described by Silvia Avallone, like the real workers described by Alessandro Portelli from his research in the Terni steelworks, refer to a different set of images, one linked to youth and the embodiment of various models of masculinity. Thus, Portelli describes on the same page "Daniele Tacconelli, a 28 year old worker who has a piercing, likes hip-hop, goes to Valencia with his friends to see the

79 In the film, however, we see the collapse of two models of masculinity, even if the director's sympathies lie with the ex-worker who manages to "reinvent" himself in a profession which allows him to recoup a virile identity.

80 Boni 2004: 31

81 Avallone 2010: 25. 
motorcycle grand prix, hangs out in the Terni movida bars and talks about his love life with his factory friends" and Tacconelli "the worker who does overtime because he has to go to a trendy shop and buy trousers by Gucci, Prada or some other cool brand, own a fancy watch, and manage the monthly payments on his car, because that way, when he goes to a disco on Saturdays, everyone says to him 'Wow, what a great car you've got'." 82 For these workers, therefore, there is a particularly close relationship between masculine identity and social identity, for the most part constructed around public spectacle. Thus, just as industrial production seems to become more and more marginalized - more so in collective representations than in the real world of manufacturing in fact - so the social figure of the worker also seems to have a declining place in the collective imagination, usually limited to moments of crisis in employment, where the worker is most often represented as a defeated man. In this context, the factory worker is no longer a model of masculinity, linked as he is to a specific professional role or to an object. Moreover, the very transformation of factory work contributes to diminish his attractive force, because his specific relationship with materiality and with creation have disappeared, aspects which, a few decades ago, exalted the physical attributes (strength), or the psychological ones (determination or willpower) of being-a-man.

Article originally in Italian, translated from the French version by Heloise FINCH-BOYER

\section{Bibliography}

Avallone, Silvia. 2010. Acciaio. Milan: Rizzoli.

BAgnasCO, Arnaldo. 1977. Tre Italie. Bologna: Il Mulino.

BALlone, Adriano. 1987. Il militante comunista torinese (1945-1955). Fabbrica, società, politica: una prima ricognizione. In I Muscoli della storia. Militanti e

82 Portelli 2008: 89. 
organizzazioni operaie a Torino 1945-1955, ed. Aldo Agosti, 88-213. Milan: Franco Angeli.

Bellassai, Sandro. 2011. L'Invenzione della virilità. Politica e immaginario maschile nell'Italia contemporanea. Rome: Carocci.

BertuCELli, Lorenzo. 1997. Nazione operaia. Cultura del lavoro e vita di fabbrica a Milano e Brescia, 1945-1963. Rome: Ediesse.

- 2004. Piazze e palazzi. Il sindacato tra fabbrica e istituzioni. La CGIL (1969-1985). Milan: Unicopli.

BIANCIARDI, Luciano. 1998 [1 st edn 1962]. La Vita agra. Milan: Bompiani.

BONI, Federico. 2004. Men's help. Sociologia dei periodici maschili. Rome: Meltemi.

CAZZullo, Aldo. 1998. I Ragazzi che volevano fare la rivoluzione. 1968-1978: storia di Lotta continua. Milan: Mondadori.

Cereseto, Giovanna, Anna, Frisone, and Laura VArlese. 2009. Non è un gioco da ragazze. Femminismo e sindacato : i coordinamenti donne FLM. Rome: Ediesse.

Contini, Gianfranco. 1999 [1997]. Rappresentazioni. Minatori e cavatori toscani si raccontano. In Tra Fabbrica e società. Mondi operai nell'Italia del Novecento, in Annali della Fondazione Giangiacomo Feltrinelli, ed. Stefano Musso a. XXXIII, 275-312. Turin: Feltrinelli.

FOFI, Goffredo. 1972. Un personaggio e un metodo. Ombre rosse 3-4: 127-129.

GARIGALI, Guiseppina. 1995. Memorie operaie. Vita, politica e lavoro a Milano 1940-1960. Milan: Franco Angeli.

GiachetTi, Diego. 2002. Anni Sessanta comincia la danza. Giovani, capelloni, studenti ed estremisti negli anni della contestazione. Pisa: Biblioteca Franco Serantini.

GIORDA, Nicoletta (ed.). 2007. Fare la differenza. L'esperienza dell'Intercategoriale donne di Torino. 1975-1986. Turin: Edizioni Angolo Manzoni.

Images from the Fiat Archives, 1940-1980. 1990. Milan: Fabbri editori.

LERNER, Gad. 1988. Operai. Viaggio all'interno della Fiat. La vita, le case, le fabbriche di una classe che non c'è più. Milan: Feltrinelli.

LeRner, Gad, Luigi, MANCONI, and Marino SinIBALDI. 1978. Uno Strano movimento di strani studenti. Composizione, politica e cultura dei non garantiti. Milan: Feltrinelli.

LOY, Gianni. 1999. Lavoro, professioni, rappresentanze: l'interpretazione delle ambivalenze. In L'Italia dopo la grande trasformazione. Trent'anni di analisi Censis 19661996, ed. Carlo Felice Casula, 87-105. Rome: Carocci.

Morando, Paolo. 2009. Dancing Days, 1978-1979. I Due anni che hanno cambiato l'Italia. Rome-Bari: Laterza. 
Negri, Antonio. 1979. Dall'operaio massa all'operaio sociale. Intervista sull'operaismo. Milan: Multhipla.

Novelui, Edoardo. 2000. C'era una volta il Pci. Autobiografia di un partito attraverso le immagini della sua propaganda. Rome: Editori Riuniti.

ONOFRI, Fabrizio. 1955. La Condizione operaia in Italia. Rome: Edizioni di cultura sociale.

OTtiero, Ottieri. 1959. Donnarumma all'assalto. Milan: Bompiani.

PACI, Massimo. 1973. Mercato del lavoro e classi sociali in Italia. Bologna: Il Mulino.

PAlandri, Enrico. 1988 [1st edn 1979]. Boccalone. Storia vera piena di bugie. Milan: L'erba voglio.

PAPUZZI, Alberto. 2007. Quando torni. Una vita operaia. Rome: Donzelli.

Passerini, Luisa, and Marcella FiLIPPA. 1997. Memorie di Mirafiori. In Mirafiori, ed. Carlo Olmo, 327-358. Turin: Umberto Allemandi \& Co.

PenNaCCHI, Antonio. 1994. Mammut. Rome: Donzelli.

Pescarolo, Alessandra. 1996. Il lavoro e le risorse delle donne in età contemporanea. In Il Lavoro delle donne, ed. Angela GropPI, 299-345. Rome-Bari: Laterza.

Piccone Stella, Simonetta. 1993. La Prima generazione. Ragazze e ragazzi nel miracolo economico italiano. Milan: Franco Angeli.

PoLO, Gabriele. 1989. I Tamburi di Mirafiori. Testimonianze operaie attorno all'autunno caldo alla Fiat. Turin: Cric.

Portell, Alessandro. 2008. Acciai speciali. Terni, la ThyssenKrupp, la globalizzazione. Rome: Donzelli.

Ravaioli, Carla. 1979. Le donne. In Dal '68 ad oggi. Come siamo e come eravamo, ed. Antonio Gambino, 317-358. Rome: Laterza.

Revelli, Marco. 1989. Lavorare in Fiat. Da Valletta ad Agnelli a Romiti. Operai Sindacati Robot. Milan: Garzanti.

SANGIOVANNI, Andrea. 2006. Tute blu. La parabola operaia nell'Italia repubblicana. Rome: Donzelli.

Urbani, Giuliano, and Maria WeBer. 1984. Cosa pensano gli operai. Lavoro, economia e politica negli orientamenti degli operai agli inizi degli anni ottanta. Milan: Franco Angeli.

VOLPONI, Paolo. 1991. Memoriale. Turin: Einaudi.

ZAMARIN, Roberto. 1972. Gasparazzo. Rome: Samonà and Savelli. 